\title{
Acquisition System for Arabic Noun Morphology
}

\author{
Saleem Abuleil Khalid Alsamara Martha Evens \\ Information System Department Computer Science Department \\ Chicago State University Illinois Institute of Technology \\ 9501 S. King Drive, Chicago, IL 6062810 West 31 Street, Chicago IL 60616 \\ s_abuleil@hotmail.com kalsamara@hotmail.com evens@iit.edu
}

\begin{abstract}
Many papers have discussed different aspects of Arabic verb morphology. Some of them used patterns; others used patterns and affixes. But very few have discussed Arabic noun morphology particularly for nouns that are not derived from verbs. In this paper we describe a learning system that can analyze Arabic nouns to produce their morphological information and their paradigms with respect to both gender and number using a rule base that uses suffix analysis as well as pattern analysis. The system utilizes user-feedback to classify the noun and identify the group that it belongs to.
\end{abstract}

\section{Introduction}

A morphology system is the backbone of a natural language processing system. No application in this field can survive without a good morphology system to support it. The Arabic language has its own features that are not found in other languages. That is why many researchers have worked in this area. Al-Fedaghi and Al-Anzi (1989) present an algorithm to generate the root and the pattern of a given Arabic word. The main concept in the algorithm is to locate the position of the root's letters in the pattern and examine the letters in the same position in a given word to see whether the tri graph forms a valid Arabic root or not.

Al-Shalabi (1998) developed a system that removes the longest possible prefix from the word where the three letters of the root must lie somewhere in the first four or five characters of the remainder. Then he generates some combinations and checks each one of them with all the roots in the file. Al-Shalabi reduced the processing, but he discussed this from point of view of verbs not nouns. Anne Roeck and Waleed Al-Fares (2000) developed a clustering algorithm for Arabic words sharing the same verbal root. They used root-based clusters to substitute for dictionaries in indexing for information retrieval. Beesley and Karttunen (2000) described a new technique for constructing finite-state transducers that involves reapplying a regular-expression compiler to its own output. They implemented the system in an algorithm called compilereplace. This technique has proved useful for handling non-concatenate phenomena, and they demonstrate it on Malay full-stem reduplication and Arabic stem inter-digitations.

Most verbs in the Arabic language follow clear rules that define their morphology and generate their paradigms. Those nouns that are not derived from roots do not seem to follow a similar set of well-defined rules. Instead there are groups showing family resemblances.

We believe that nouns in Arabic that are not derived from roots are governed not only by phonological rules but by lexical patterns that must be identified and stored for each noun. Like irregular verbs in English their forms are determined by history and etymology, not just phonology. Among many other examples, Pinker (1999) points to the survival of past forms became for become and overcame for overcome, modeled on came for come, while succumb, with the same sound pattern, has a regular past form succumbed. The same kinds of phenomena are especially apparent for proper nouns in Arabic derived from Indian and Persian names. Pinker uses examples like this, as well as emerging research in neurophysiology, to argue for the coexistence of phonological rules and lexical storage of English verb patterns. 
We believe that further work in Arabic computational linguistics requires the development of a pattern bank for nouns. This paper describes the tool that we have built for this purpose. While the set of patterns for common nouns in Arabic may soon be established, newspapers and other dynamic sources of language will always contain new proper names, so we expect our tool to be a permanent part of our system, even though we may need it less often as time goes on.

\section{Nouns in the Arabic Language}

A noun in Arabic is a word that indicates a meaning by itself without being connected with the notion of time. There are two main kinds of noun: variable and invariable. Variable nouns have different forms for the singular, the dual, the plural, the diminutive, and the relative. Variable nouns are again divided into two kinds: inert and derived. The inert noun is not derived from another word, i.e. it does not refer to a verbal root. Inert nouns are divided into two kinds: concrete nouns (e.g., lion), and abstract nouns (e.g., love). Derived nouns are taken from another word (usually a verb) (e.g. office); they have a root to refer to. A derived noun is usually close to its root in meaning. It indicates, besides the meaning, the concrete thing that caused its formation (case of the agent-noun), or underwent its action (case of the patient-noun), or any other notions of time, place, or instrument. The following are the noun types:

A genus noun indicates what is common to every element of the genus without being specific to any one of them. It is the word naming a person, an animal, a thing or an idea. Example: رجل

An agent noun is a derived noun indicating the actor of the verb or its behavior. It has several patterns according to its root. Example:

دارس

A patient noun is a derived noun indicating the person or thing that undergoes the action of the verb. Patient nouns have several patterns depending in the verbal root. Example:

مدروس the thing that has been studied

An instrument noun is a noun indicating the tool of an action. Some instruments are derived; some are inert. Example: مفتاح key

An adjective is considered to be a type of noun in traditional Arabic grammar. It describes the state of the modified noun. Example: جيل beautiful سيد Mr. كبير Pig

An adverb is a noun that is not derived and that indicates the place or the time of the action. Example:

$$
\text { شonth مدينة north }
$$

A proper noun is the name of a specific person, place, organization, thing, idea, event, date, time, or other entity. Some of them are solid (inert) nouns some of them are derived [Abuleil and Evens 1998].

\section{Noun Classification}

In this paper we focus on the following nouns: genus nouns, agent nouns, instrument nouns, adjectives, proper adjectives (adjectives derived from proper nouns), proper nouns, and adverbs. Some of these nouns are not derived from verbs and some are. All of these nouns use the same pattern when it comes to the dual form either for masculine or feminine, but there are many ways to form the plural noun. Some of the nouns have both masculine and feminine forms, some of them have just feminine forms and some have just masculine forms. A few nouns use the same format for both the plural and the dual (e.g. مدرسين teachers used for both dual and plural) For most nouns, when they end with the letter (o), this indicates the feminine form of the noun, sometimes it does not, but it changes the meaning of the noun completely (e.g. مكتب office, مكتبة library). Sometimes the same consonant string with different vowels has different meanings (e.g. مدرسة school, مدرسة teacher). Nouns are not like verbs in the Arabic language, there is no clear rule to define the morphological information and generate the morphology paradigms for them. Instead each group of nouns follows its own pattern.

We have classified the nouns into 84 groups according to their patterns for singular, plural, masculine and feminine. We generated a method for each group to be used to find the morphological information and to form its paradigm. Very few of these groups have a 
unique pattern for plural and singular; and most of them share the same pattern with other groups. Table 1 shows some examples of these groups and their patterns. The digit 9 stands for

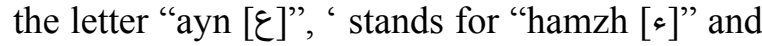
(a) stands for "ta [0]" since there is no corresponding letters in English for these letters.

Table 1. Pattern Classification

\begin{tabular}{|c|c|c|c|}
\hline S-M & S-F & P-M & P-F \\
\hline f91 & $\mathrm{X}$ & af9al & $\mathrm{X}$ \\
\hline f91 & f91@ & af9la' & af9la' \\
\hline$X$ & f91@ & $\mathrm{X}$ & $\mathrm{f} 91$ \\
\hline fa9l & fa91@ & f9al/f9l@ & f9al/f9l@ \\
\hline f9al & $X$ & $\mathrm{X}$ & af91@ \\
\hline $\mathrm{mf} 91$ & $\mathrm{X}$ & mfa91 & $X$ \\
\hline fa9wl & $\mathrm{X}$ & fwa9el & $X$ \\
\hline $\mathrm{mf} 9 \mathrm{el}$ & $X$ & mfa9el & $X$ \\
\hline $\mathrm{X}$ & fa91@ & $\mathrm{X}$ & fa9lat \\
\hline f9el & f9el@ & f9la' & f9la' \\
\hline
\end{tabular}
S: Singular
F: Feminine
P: Plural
M: Masculine
$\mathrm{X}$ : not available

\section{$4 \quad$ Acquisition System}

The system reads the next noun in the text, isolates and analyzes the suffixes of the noun, generates its pattern, and uses either the Classified Noun Table, the Suffix/Pattern Analysis or the User-Feedback Module to find the group to which the noun belongs to identify the rules that applies to this group to generate all morphological paradigms with respect to the number and gender and updates the database. The system consists of several modules as shown in Figure 1.

\subsection{Interface Module}

This graphical user interface allows the user to interact with the system and handles the input/output. This module displays a main menu with two main options: collect nouns from documents and find morphological information.

\subsection{Type-Finder Module}

The main function of this module is to read the document and find the part of speech of the word: noun, verb, adjective, particle or proper noun by running several tests: Database lookup, particle check, check on adjectives derived from proper nouns, parse of noun phrases and verb phrases, the affix check and the pattern check This module was built by Abuleil and Evens $(1998,2001)$. We use this module in our new system to find all nouns and extract them from the text.

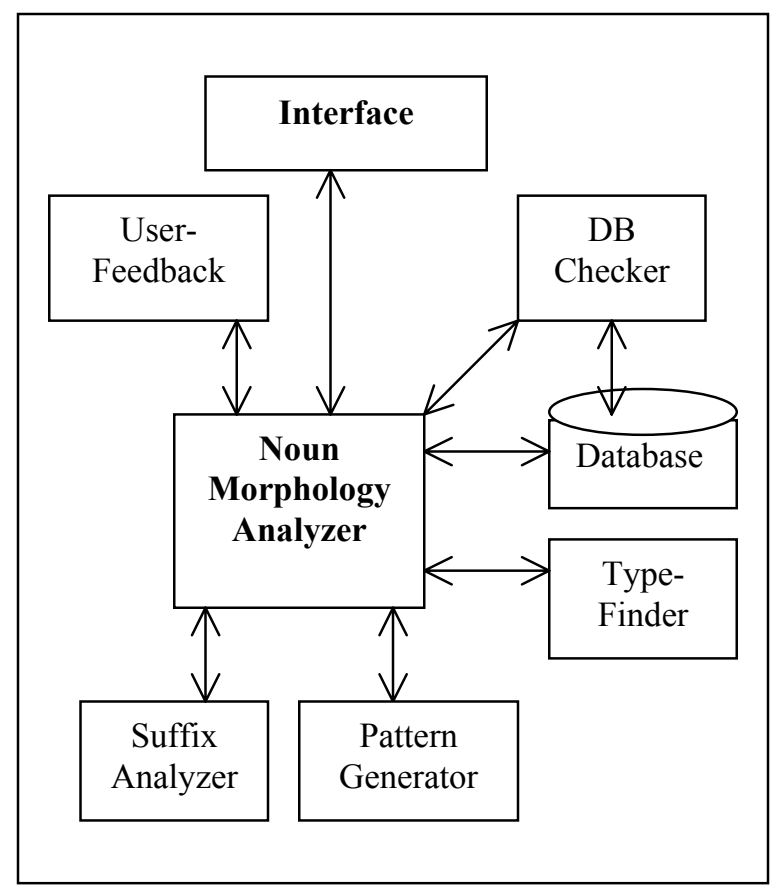

Figure 1. The Acquisition System

\subsection{Database}

The database includes a Classified Noun Table that contains each root noun (singular: masculine or feminine) and the number of the group to which the noun belongs. Each time the system identifies a new noun it adds its root to the Classified Noun Table.

\subsection{Noun Morphology Analyzer Module}

This is the core of the system, it calls different modules and performs different tasks to identify the noun and find its paradigm. First, it passes the noun to the suffix analyzer module to drop the suffix. Second, it passes it to the pattern generator module to find the pattern. Third, it analyzes the pattern to see whether it belongs to more than one group. It checks the Classified Nouns Table and then the suffix/pattern to 
identify the group that the noun belongs to. If the system cannot identify the group then it calls the user-Feedback module to produce some questions to be answered by the user to reduce the number of alternatives to one. Finally, depending on the group the noun belongs to, it generates the morphological paradigms for number and gender and updates the database.

\subsection{Suffix Analyzer Module}

This module identifies the suffix, analyzes it and produces some lexical information about the noun like number and gender. First, it checks if any pronoun is concatenated with the noun. Second, it checks for a suffix indicating number. Third, it checks for a suffix indicating gender.

When the letter (ي) comes at the end of the noun there are two cases: it could be a part of the noun so we should not drop it, or it could be an extra letter as in relative nouns or when the pronoun is connected to the noun and it should be dropped in this case. When the noun ends with the letters (ين), most of the time it represents dual nouns but some times it represents both plural and dual nouns as in the following patterns: mfa91, fa91, mf9ull. Sometimes we have to check the pattern also to help in analyzing the suffix. We will handle these problems as special cases.

\subsection{Pattern Generator Module}

We have collected 62 different patterns used for both masculine and feminine, singular and plural after the suffix has been dropped see Appendix A. We used these patterns to generate a set of rules to build a finite-state diagram to be used to find the pattern for any noun. The input to this module is a noun after its suffix has been dropped in the previous step, the output is one or more patterns. If more than one pattern is found we validate the string by checking the pattern table.

The letter (P) and the letter (l) at the beginning of the noun are sometimes the first characters of the noun, but sometimes they are separate words. We collected the nouns that begin with the letter ( $(\curvearrowright)$ and the letter $(I)$ and saved them in a file to help us to distinguish between these two cases.

\subsection{Database Checker Module}

This module identifies any already classified noun or any noun derived from it. It gets the noun and its pattern from the noun morphology analyzer, finds all groups that contain the pattern, finds the singular noun (masculine or feminine) in each group and uses it to check the Classified Noun Table. If the noun exists it gets the group number to which it belongs and passes it to the Noun Morphology Analyzer to generate the results. For example the noun (ملاعب) playground) has the pattern (mfa9l). This pattern appears in three different groups. See table 2.

Table 2. The Groups of the Noun "ملاعب"

\begin{tabular}{|l|l|l|l|l|}
\hline Group\# & $\begin{array}{l}\text { Sing. } \\
\text { Masc. }\end{array}$ & $\begin{array}{l}\text { Sing } \\
\text { Fem. }\end{array}$ & $\begin{array}{l}\text { Plural } \\
\text { Masc. }\end{array}$ & $\begin{array}{l}\text { Plural } \\
\text { Fem. }\end{array}$ \\
\hline 1 & X & mf91@ & X & Mfa91 \\
\hline 2 & Mf91 & X & X & Mfa9l \\
\hline 3 & mfa9l & mf91@ & $\begin{array}{l}\text { mf9lun/ } \\
\text { mf9len }\end{array}$ & ملعبات \\
\hline
\end{tabular}

The nouns formed from these patterns have the following paradigms. See table 3.

Table 3. The Paradigms of the Noun "ملاعب"

\begin{tabular}{|c|c|c|c|c|}
\hline Group\# & $\begin{array}{l}\text { Sing. } \\
\text { Masc. }\end{array}$ & $\begin{array}{l}\text { Sing } \\
\text { Fem. }\end{array}$ & $\begin{array}{l}\text { Plural } \\
\text { Masc. }\end{array}$ & $\begin{array}{l}\text { Plural } \\
\text { Fem. }\end{array}$ \\
\hline 1 & $\mathrm{X}$ & ملعبة & $X$ & ملاعب \\
\hline 2 & ملعب & $X$ & $X$ & ملاعب \\
\hline 3 & ملاعب & ملعبة & ملعبيون & ملعبات \\
\hline
\end{tabular}

If the noun itself or any other noun derived from it has been previously classified we will find its noun root (singular noun) in the Classified Noun Table. The module will find the root (singular masculine) "ملعب in the table and will get its group number "2" and pass it to Noun Morphology Analyzer to find the noun paradigms.

\subsection{User-Feedback Module}

This module gets all alternatives (groups) from the noun morphology analyzer module. It analyzes them and generates some questions to be answered by the user. It gets the answers, analyzes them and finds the group that the noun belongs to. The module asks questions like: Is the noun a singular? Is the noun a plural? Does 
the noun have a masculine-singular format? Does the noun have a feminine-singular format?

Example:

Input: The noun (ملاعب playground)

Pattern: mfa9l

Number of groups that contain the pattern is 3 .

\section{Process:}

Step \#1: identify the groups

\begin{tabular}{|l|l|l|l|l|}
\hline Group\# & $\begin{array}{l}\text { Sing. } \\
\text { Masc. }\end{array}$ & $\begin{array}{l}\text { Sing. } \\
\text { Fem. }\end{array}$ & $\begin{array}{l}\text { Plural } \\
\text { Masc. }\end{array}$ & $\begin{array}{l}\text { Plural } \\
\text { Fem. }\end{array}$ \\
\hline 1 & $\mathrm{X}$ & $\mathrm{mf91@}$ & $\mathrm{X}$ & $\mathrm{mfa91}$ \\
\hline 2 & $\mathrm{mf91}$ & $\mathrm{X}$ & $\mathrm{X}$ & $\mathrm{mfa91}$ \\
\hline 3 & $\mathrm{mfa} 91$ & $\mathrm{mf91@}$ & $\begin{array}{l}\mathrm{mf9lun} / \\
\mathrm{mf9len}\end{array}$ & mf9lat \\
\hline
\end{tabular}

Step \#2: Replace (X) with -1, given pattern with 1 and any thing else with 0 .

\begin{tabular}{|l|c|c|c|c|}
\hline Group\# & $\begin{array}{l}\text { Sing. } \\
\text { Masc. }\end{array}$ & $\begin{array}{l}\text { Sing. } \\
\text { Fem. }\end{array}$ & $\begin{array}{l}\text { Plural } \\
\text { Masc. }\end{array}$ & $\begin{array}{l}\text { Plural } \\
\text { Fem. }\end{array}$ \\
\hline 1 & -1 & 0 & -1 & 1 \\
\hline 2 & 0 & -1 & -1 & 1 \\
\hline 3 & 1 & 0 & 0 & 0 \\
\hline
\end{tabular}

Step \#3: Add the one's in each column and subtract it from number of groups. Add the (1 's) in each column and subtract it from number of groups. Add the (0's) in each column.

\begin{tabular}{|l|c|c|c|c|}
\hline Group\# & $\begin{array}{l}\text { Sing. } \\
\text { Masc. }\end{array}$ & $\begin{array}{l}\text { Sing. } \\
\text { Fem. }\end{array}$ & $\begin{array}{l}\text { Plural } \\
\text { Masc. }\end{array}$ & $\begin{array}{l}\text { Plural } \\
\text { Fem. }\end{array}$ \\
\hline 1 & -1 & 0 & -1 & 1 \\
\hline 2 & 0 & -1 & -1 & 1 \\
\hline 3 & 1 & 0 & 0 & 0 \\
\hline $\mathbf{A}=\Sigma \mathbf{1}$ 's & $\mathbf{1}$ & $\mathbf{0}$ & $\mathbf{0}$ & $\mathbf{2}$ \\
\hline $\mathbf{B}=\Sigma-\mathbf{1}$ 's & $\mathbf{1}$ & $\mathbf{1}$ & $\mathbf{2}$ & $\mathbf{0}$ \\
\hline $\mathbf{C}=\Sigma \mathbf{0}$ 's & $\mathbf{1}$ & $\mathbf{2}$ & $\mathbf{1}$ & $\mathbf{1}$ \\
\hline $\mathbf{A 1}=$ \#G $-\mathbf{A}$ & $\mathbf{2}$ & $\mathbf{3}$ & $\mathbf{3}$ & $\mathbf{1}$ \\
\hline $\mathbf{B 1}=$ \#G $\mathbf{- B}$ & $\mathbf{2}$ & $\mathbf{2}$ & $\mathbf{1}$ & $\mathbf{3}$ \\
\hline
\end{tabular}

From the table above we know that: the probability that the noun is singular masculine is $33.3 \%$ and the probability that it is a plural feminine is $66.6 \%$.

Step \#4: Pick the smallest value greater than 0 from the "A1" row and the "B1" row go from left to right and from top to bottom. Use the column name to form questions. For the "A1" value use the following question: is the noun a [column name]? For the "B1" use the following question: does the noun have the [column name] format? Get the answer and drop invalid group(s).

\begin{tabular}{|l|c|c|c|c|}
\hline Group\# & $\begin{array}{l}\text { Sing. } \\
\text { Masc. }\end{array}$ & $\begin{array}{l}\text { Sing. } \\
\text { Fem. }\end{array}$ & $\begin{array}{l}\text { Plural } \\
\text { Masc. }\end{array}$ & $\begin{array}{l}\text { Plural } \\
\text { Fem. }\end{array}$ \\
\hline 1 & -1 & 0 & -1 & 1 \\
\hline 2 & 0 & -1 & -1 & 1 \\
\hline $\mathbf{A}=\boldsymbol{\Sigma} \mathbf{1}$ 's & $\mathbf{0}$ & $\mathbf{0}$ & $\mathbf{0}$ & $\mathbf{2}$ \\
\hline $\mathbf{B}=\Sigma-\mathbf{1}$ 's & $\mathbf{1}$ & $\mathbf{1}$ & $\mathbf{2}$ & $\mathbf{0}$ \\
\hline $\mathbf{C}=\boldsymbol{\mathbf { 0 }} \mathbf{\mathbf { 0 }}$ 's & $\mathbf{1}$ & $\mathbf{1}$ & $\mathbf{0}$ & $\mathbf{0}$ \\
\hline $\mathbf{A 1}=$ \#G $-\mathbf{A}$ & $\mathbf{2}$ & $\mathbf{2}$ & $\mathbf{2}$ & $\mathbf{0}$ \\
\hline B1 $=$ \#G $-\mathbf{B}$ & $\mathbf{1}$ & $\mathbf{1}$ & $\mathbf{0}$ & $\mathbf{2}$ \\
\hline
\end{tabular}

Step \#5: Repeat step 3 and step 4 until you end up with one group or all the values in both Row A1 and row B1 have the values either zero or the number of groups left.

Step \#6: if more than one group is left from step \#5 then find the largest value in the row " $C$ " from left to right and ask the following question: which of the following [list all the options in that column] is the [column name] of the noun?

\begin{tabular}{|c|c|c|c|c|}
\hline $\begin{array}{c}\text { Group } \\
\#\end{array}$ & $\begin{array}{c}\text { Sing. } \\
\text { Masc. }\end{array}$ & $\begin{array}{l}\text { Sing. } \\
\text { Fem. }\end{array}$ & $\begin{array}{l}\text { Plural } \\
\text { Masc. }\end{array}$ & $\begin{array}{l}\text { Plural } \\
\text { Fem. }\end{array}$ \\
\hline 2 & 0 & -1 & -1 & 1 \\
\hline $\mathbf{A}=\boldsymbol{\Sigma} \mathbf{1}$ 's & $\mathbf{0}$ & $\mathbf{0}$ & $\mathbf{0}$ & $\mathbf{1}$ \\
\hline $\mathbf{B}=\Sigma-\mathbf{1}$ 's & $\mathbf{0}$ & $\mathbf{1}$ & $\mathbf{1}$ & $\mathbf{0}$ \\
\hline $\mathbf{C}=\boldsymbol{\mathbf { 1 }} \mathbf{0}$ 's & $\mathbf{1}$ & $\mathbf{0}$ & $\mathbf{0}$ & $\mathbf{0}$ \\
\hline $\mathbf{A 1}=\# \mathbf{G}-\mathbf{A}$ & $\mathbf{1}$ & $\mathbf{1}$ & $\mathbf{1}$ & $\mathbf{0}$ \\
\hline $\mathbf{B 1}=\# \mathbf{G}-\mathbf{B}$ & $\mathbf{1}$ & $\mathbf{0}$ & $\mathbf{0}$ & $\mathbf{1}$ \\
\hline
\end{tabular}

The questions the module generated from the previous example are:

Q1: is the noun plural feminine?

Answer: yes // the system drops group\#3

Q2: does the noun have singular masculine format?

Answer: No // the system drops group\#1

\section{Result:}

Group \# 2: The noun (ملاعب playground) is a plural Feminine. The singular Masculine format is (ملعب), the singular Feminine format and plural masculine format are not available for this noun. 


\section{$5 \quad$ Examples}

The following example shows how the system works. Assume that the input is the noun (مدربتهم) their trainer), First the system calls the suffix analyzer module to drop the extra letter (pronoun: their) at the end (مدربت + هم), replace the letter $(ت)$ with the letter $(*)$, generate the noun ( مدربة trainer) and some lexical information about the noun.

Second, it passes the noun (مدربة trainer) to the pattern generator module to generate the pattern(mf91@). Third, it checks the group table looking for this pattern (mf91@). Fourth, if more that one group is found it uses the Database Checker Module to check the Classified Noun Table. Fifth, if the noun does not exist in the table, it calls the User-Feedback Module to analyze the groups (all alternatives) and asks the user some questions to assist in identifying the group see Table 4 and Table 5 . The question that the module generated is:

Question: Does the noun have a masculinesingular format?

Answer: Yes

Result: drop group \# 10 \& group \# 22

Table 4. First Cycle to Generate Question

\begin{tabular}{|l|c|c|c|c|}
\hline Group \# & $\begin{array}{l}\text { Sing. } \\
\text { Masc. }\end{array}$ & $\begin{array}{l}\text { Sing } \\
\text { Fem. }\end{array}$ & $\begin{array}{l}\text { Plural } \\
\text { Masc. }\end{array}$ & $\begin{array}{l}\text { Plural } \\
\text { Fem. }\end{array}$ \\
\hline 10 & -1 & 1 & 0 & -1 \\
\hline 22 & -1 & 1 & 0 & -1 \\
\hline 38 & 0 & 1 & 0 & 0 \\
\hline $\mathbf{A}=\Sigma \mathbf{1}$ 's & $\mathbf{0}$ & $\mathbf{3}$ & $\mathbf{0}$ & $\mathbf{0}$ \\
\hline $\mathbf{B}=\Sigma-\mathbf{1}$ 's & $\mathbf{2}$ & $\mathbf{0}$ & $\mathbf{0}$ & $\mathbf{2}$ \\
\hline $\mathbf{C}=\Sigma \mathbf{0}$ 's & $\mathbf{1}$ & $\mathbf{0}$ & $\mathbf{3}$ & $\mathbf{1}$ \\
\hline $\mathbf{A 1}=$ \#G - A & $\mathbf{3}$ & $\mathbf{0}$ & $\mathbf{3}$ & $\mathbf{3}$ \\
\hline $\mathbf{B 1}=$ \#G $-\mathbf{B}$ & $\mathbf{1}$ & $\mathbf{3}$ & $\mathbf{3}$ & $\mathbf{1}$ \\
\hline
\end{tabular}

Table 5. Second Cycle to Generate Question

\begin{tabular}{|l|c|c|c|c|}
\hline Group \# & $\begin{array}{l}\text { Sing. } \\
\text { Masc. }\end{array}$ & $\begin{array}{l}\text { Sing } \\
\text { Fem. }\end{array}$ & $\begin{array}{c}\text { Plural } \\
\text { Masc. }\end{array}$ & $\begin{array}{c}\text { Plural } \\
\text { Fem. }\end{array}$ \\
\hline 38 & 0 & 1 & 0 & 0 \\
\hline $\mathbf{A}=\Sigma \mathbf{1}$ 's & $\mathbf{0}$ & $\mathbf{1}$ & $\mathbf{0}$ & $\mathbf{0}$ \\
\hline $\mathbf{B}=\Sigma-\mathbf{1}$ 's & $\mathbf{0}$ & $\mathbf{0}$ & $\mathbf{0}$ & $\mathbf{0}$ \\
\hline $\mathbf{C}=\Sigma \mathbf{0}$ 's & $\mathbf{1}$ & $\mathbf{0}$ & $\mathbf{1}$ & $\mathbf{1}$ \\
\hline $\mathbf{A 1}=$ \#G $-\mathbf{A}$ & $\mathbf{1}$ & $\mathbf{0}$ & $\mathbf{1}$ & $\mathbf{1}$ \\
\hline $\mathbf{B} 1=$ \#G $-\mathbf{B}$ & $\mathbf{1}$ & $\mathbf{1}$ & $\mathbf{1}$ & $\mathbf{1}$ \\
\hline
\end{tabular}

Fifth, it generates the results: group\#38 and updates the database. Table 6 shows system output for some input.

Table 6. System Output

\begin{tabular}{|c|c|c|c|c|}
\hline Noun & $\begin{array}{l}\text { مفاتيح } \\
\text { keys }\end{array}$ & $\begin{array}{l}\text { طائرة } \\
\text { plane }\end{array}$ & $\begin{array}{c}\text { صوتتا } \\
\text { Our } \\
\text { sound }\end{array}$ & كريمين \\
\hline Suffix & ---- & ---- & نا & ين \\
\hline Pattern & $\begin{array}{c}\text { مفاعيل } \\
\text { mfa9el }\end{array}$ & $\begin{array}{c}\text { فاعلة } \\
\text { fa91@ }\end{array}$ & $\begin{array}{l}\text { فعل } \\
\text { f91 }\end{array}$ & $\begin{array}{l}\text { فعيل } \\
\text { f9el }\end{array}$ \\
\hline Group \# & 52 & 23 & 3 & 37 \\
\hline Result & $\begin{array}{l}\text { Plural } \\
\text { masc. }\end{array}$ & $\begin{array}{l}\text { Singular } \\
\text { Feminine }\end{array}$ & $\begin{array}{l}\text { Singular } \\
\text { feminine }\end{array}$ & $\begin{array}{l}\text { Dual / } \\
\text { plural } \\
\text { masc. }\end{array}$ \\
\hline $\begin{array}{l}\text { Singular } \\
\text { / Masc. }\end{array}$ & مفتاح & $\mathrm{X}$ & صوت & كريم \\
\hline $\begin{array}{l}\text { Singular } \\
\text { / Fem. }\end{array}$ & $\mathrm{X}$ & طائرة & $\mathrm{X}$ & كريمة \\
\hline $\begin{array}{l}\text { Plural / } \\
\text { Masc. }\end{array}$ & $\mathrm{X}$ & $\mathrm{X}$ & $\mathrm{X}$ & / كريمين \\
\hline $\begin{array}{l}\text { Plural / } \\
\text { Fem. }\end{array}$ & مفاتيح & طائر ات & اصو ات & كريمات \\
\hline $\begin{array}{l}\text { Dual / } \\
\text { Masc. }\end{array}$ & مفتاحان & $\bar{X}$ & صوتين & كريمان \\
\hline $\begin{array}{l}\text { Dual / } \\
\text { Fem. }\end{array}$ & $\mathrm{X}$ & طائرتين & $\mathrm{X}$ & كريمتين \\
\hline
\end{tabular}

\section{$6 \quad$ Results}

To test our system we used nouns obtained from a corpus developed by Ahmad Hasnah based on text given to Illinois Institute of Technology, by the newspaper, Al-Raya, published in Qatar. We have tested each module in our system: the suffix analyzer modules, the pattern generator module, and the user-Feedback module. Table 7 shows the result of testing the system on 500 nouns.

Table 7. Suffix / Pattern / Noun Morphology Analyzer

\begin{tabular}{|c|c|c|c|c|}
\hline & $\begin{array}{c}\# \\
\text { correct }\end{array}$ & $\begin{array}{c}\# \\
\text { incorrect }\end{array}$ & $\begin{array}{c}\% \\
\text { correct }\end{array}$ & $\begin{array}{c}\% \\
\text { incorrect }\end{array}$ \\
\hline $\begin{array}{c}\text { Suffix } \\
\text { Analyzer }\end{array}$ & 490 & 10 & $97 \%$ & $3 \%$ \\
\hline $\begin{array}{c}\text { Pattern } \\
\text { Analyzer }\end{array}$ & 471 & 29 & $93 \%$ & $8 \%$ \\
\hline $\begin{array}{c}\text { Noun } \\
\text { Morph } \\
\text { analyzer }\end{array}$ & 451 & 49 & $90.2 \%$ & $9.8 \%$ \\
\hline
\end{tabular}

As shown in Table 7 there were ten failure because of incorrect suffix analysis and 29 due 
to missing patterns. These missing patterns have now been added. The suffix analysis problem is hard to correct because it arises from underlying ambiguities. If the noun has been classified previously the system does not have any problem to identify it and identify any noun derived from it.

The User-Feedback Module found most of the nouns that the Database Checker Module failed to identify. Table 8 shows a number of nouns identified by suffix/pattern, nouns identified by Database Checker Module and nouns identified by User-Feedback Modules. We believe that the more knowledge that the system gains and the more nouns that it adds to the Classified Noun Table the fewer questions have to be asked.

Table 8. Noun Classifier Methods

\begin{tabular}{|c|c|c|}
\hline $\begin{array}{c}\text { Nouns } \\
\text { Identified by } \\
\text { Database } \\
\text { Checker }\end{array}$ & $\begin{array}{c}\text { Nouns } \\
\text { Identified by } \\
\text { Suffix/ } \\
\text { Pattern } \\
\text { Analysis }\end{array}$ & $\begin{array}{c}\text { Nouns Identified } \\
\text { by } \\
\text { User-Feedback } \\
\text { Module }\end{array}$ \\
\hline 144 & 32 & 289 \\
\hline $28.8 \%$ & $7.1 \%$ & $64.1 \%$ \\
\hline
\end{tabular}

\section{Conclusion}

We have built a learning system that utilizes user feedback to identify the nouns in the Arabic language, obtain their features and generate their paradigms with respect to number and gender. We tested the system on 500 nouns from newspaper text. The system identified $90.2 \%$ of them, $7.1 \%$ by just analyzing the suffix and the pattern of the noun, $28.8 \%$ by using the Database Checker Module and the Classified Noun Table and $64.1 \%$ by using User-Feedback Module. The system failed on $9.8 \%$ of the tested nouns.

\section{References}

Abuleil, S. and Evens, M., 1998. "Discovering Lexical Information by Tagging Arabic Newspaper Text", Workshop on Semitic Language Processing. COLING-ACL'98,
University of Montreal, Montreal, PQ, Canada, Aug 16 1998, pp 1-7.

Abuleil, S. and Evens, M., 2002. Extracting an Arabic Lexicon from Arabic Newspaper Text. Computers and the Humanities, 36(2), pp. 191221.

Al-Fedaghi, Sabah and Al-Anzi, Fawaz, 1989. "A New Algorithm to Generate Arabic RootPattern Forms". Proceedings of the $11^{\text {th }}$ National Computer Conference, King Fahd University of Petroleum \& Minerals, Dhahran, Saudi Arabia., pp 4-7.

Al-Shalabi, R. and Evens, M., 1998. "A Computational Morphology System for Arabic". Workshop on Semitic Language Processing. COLING-ACL'98, University of Montreal, Montreal, PQ, Canada, Aug 16 1998. pp. 66-72.

Beesley, K. and Karttunen, L., 2000. "FiniteState Non-Concatenative Morphotactics". Proceedings of the $38^{\text {th }}$ Annual Meeting of the Association for Computational Linguistics. Hong Kong, Oct 1-8, 2000. pp.191-198.

Hasnah, A., 1996. Full Text Processing and Retrieval: Weight Ranking, Text Structuring, and Passage Retrieval For Arabic Documents. Ph.D. Dissertation, Illinois Institute of Technology, Chicago, IL.

Roeck, A. and Al-Fares, W., 2000. "A Morphologically Sensitive Clustering Algorithm for Identifying Arabic Roots". Proceedings of the $38^{\text {th }}$ Annual Meeting of the Association for Computational Linguistics. Hong Kong, Oct 1-8, 2000. pp.199-206.

\section{Appendix A. Patterns}

\begin{tabular}{|c|c|c|}
\hline Pattern & Used for & Example \\
\hline f91 & sing - masc. & جمل \\
\hline f91 & plural - masc. & جزر \\
\hline 191 & plural - fem. / masc. & عرب \\
\hline f91 & plural - fem. & صور \\
\hline f91 & sing - masc. & ضوء \\
\hline f91@, & sing. - fem. & صورة \\
\hline mf9al & sing. masc. & مفتاح \\
\hline
\end{tabular}




\begin{tabular}{|c|c|c|}
\hline Pattern & Used for & Example \\
\hline f91@ & plural - masc. & قتلة ق مقلة \\
\hline aft9al & sing. - masc. & اختر اع \\
\hline anf9al & sing. - masc. & انفجار \\
\hline astf9al & sing. - masc. & استثمار \\
\hline af9al & plural - fem. & اشجار \\
\hline af9la' & plural - fem. / masc. & اغنياء \\
\hline af91@ & plural - fem. & ادوية \\
\hline af9el & sing. - masc. & ابريق \\
\hline afa9el & plural - fem. & اباريق \\
\hline f9lawat & plural - fem. & حمر او ات \\
\hline fwa91 & plural - fem. & جو امع \\
\hline fwa9el & plural - fem. & مو ازين \\
\hline fe9al & sing- masc. & ميز ان \\
\hline f9lan & plural - fem. & غز ل الان \\
\hline f9all & plural - fem. & ق قتابل \\
\hline tf91@ & plural - fem. & تكلفة \\
\hline f9w1@, & plural -fem. & حكومة \\
\hline f9wl & sing. - masc. & عمود \\
\hline f911@ & sing- fem. & قنبلة \\
\hline f91e@ & sing. - fem. & جمعية \\
\hline f9le & sing.- masc. & صحفي \\
\hline f9el & sing - masc. & كريم \\
\hline f9el@ & sing.- fem. & جزيرة \\
\hline f9al & sing.- masc. & مطار \\
\hline f9al & plural - fem. & جمال \\
\hline f9ale & plural - fem. & صحاري \\
\hline fa91 & sing. - masc. & عالم \\
\hline fa91@ & sing. - fem. & باخرة \\
\hline f9al@ & sing. - fem. & خسارة \\
\hline f9al & plural - masc. & سجاد \\
\hline f9la' & plural - masc. & علماء \\
\hline f9la' & sing. - fem. & حمر اء \\
\hline f9alel & plural - fem. / masc. & جماهير \\
\hline fa9wl & sing. masc. & صاروخ \\
\hline f9a'l & plural - fem. & حقائب \\
\hline tf9el & sing. - masc. & تمرين \\
\hline f9lwl & sing. - masc. & جمهور \\
\hline tfa9el & plural - fem. & ت تمارين \\
\hline fw91@ & sing. - fem. & جو هرة \\
\hline f9wal & sing. - masc. & عنوان \\
\hline f9awel & plural - fem. & عناوين \\
\hline mf91@ & sing. - fem. & منجرة \\
\hline mfa91 & plural - fem. & مناجر \\
\hline mf91 & sing. - masc. & مدرس \\
\hline mf91@ & sing. - fem. & مدرسة \\
\hline mf9l & sing. - masc. & مكتب \\
\hline mf91@ & sing. - fem. & مكتبة \\
\hline mft91 & sing. masc. & معتقل \\
\hline
\end{tabular}

\begin{tabular}{|c|c|c|}
\hline Pattern & Used for & Example \\
\hline Mstf91 & sing. - masc. & مستخدم \\
\hline mf911 & sing. - masc. & مسلسل \\
\hline Mstf9a & sing. fem. & مستشفى \\
\hline mf9wl@ & sing. - fem. & موسو عة \\
\hline mf9el & sing. masc. & منديل \\
\hline mfa9el & plural - fem. & مناديل \\
\hline mf9le@, & sing. - fem. & مسرحية \\
\hline mfa91 & sing. - masc. & مقاتل \\
\hline mfa91@ & sing. - fem. & مظاهرة \\
\hline mf9wl & sing. - masc. & مشروع \\
\hline mfa9el & plural - fem. & مشاريع \\
\hline
\end{tabular}

